\title{
Moisture desorption isotherms of cucumber seeds: modeling and thermodynamic properties ${ }^{1}$
}

\author{
Paulo Cesar Corrêa ${ }^{2}$, Maycon Fagundes Teixeira Reis ${ }^{3}$, Gabriel Henrique Horta \\ de Oliveira ${ }^{4 *}$, Ana Paula Lelis Rodrigues de Oliveira ${ }^{4}$, Fernando Mendes Botelho ${ }^{5}$
}

\begin{abstract}
Hygroscopic equilibrium curves or sorption isotherms are important in order to define dehydration limits of the product, estimate moisture content alterations under environment conditions and to acquire moisture content values for safe storage. This work aimed to determine desorption isotherms of cucumber seeds stored at different temperature $(10,20,30,40$ and $\left.50{ }^{\circ} \mathrm{C}\right)$ and relative humidity $(0.11$ to 0.96$)$ and the thermodynamic properties of this process. Mathematical models were fitted to experimental data in order to represent the agricultural products hygroscopicity. Net isosteric heat of desorption was performed based on the Clausius-Clapeyron thermodynamic relation and Gibbs free energy through the Van't Hoff equation. Based on statistical parameters, Modified Henderson model was the one that best represented hygroscopicity of cucumber seeds. Equilibrium moisture content of cucumber seeds decreased with temperature increment at a constant value of relative humidity. Differential enthalpy values, representing the energy required to remove moisture from the cucumber seeds, ranged

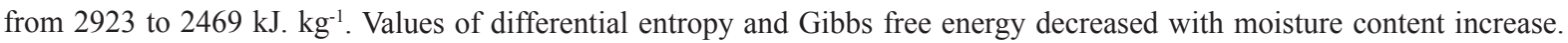
Enthalpy-entropy compensation theory is valid for the sorption of cucumber seeds, in which the water sorption mechanism in cucumber seeds can be considered to be enthalpy controlled.
\end{abstract}

Index terms: equilibrium moisture content, entropy, gibbs free energy, Cucumis sativus $\mathrm{L}$.

\section{Isotermas de dessorção de água em sementes de pepino: modelagem e propriedades termodinâmicas}

\begin{abstract}
RESUMO - Isotermas de sorção são importantes para definir os limites de desidratação do produto, estimar o teor de água e seu valor para o armazenamento seguro. Objetivou-se determinar as isotermas de dessorção de sementes de pepino armazenadas em diferentes temperaturas $\left(10,20,30,40\right.$ e $\left.50^{\circ} \mathrm{C}\right)$ e umidade relativa $(0,11-0,96)$ do ar e determinar as propriedades termodinâmicas deste processo. Modelos matemáticos foram ajustados aos dados experimentais para representar a higroscopicidade. O calor isostérico de dessorção foi calculado baseado na relação termodinâmica de Clausius-Clapeyron e a energia livre de Gibbs por meio da equação de Van’t Hoff. Henderson modificado foi o modelo que melhor representou a higroscopicidade das sementes de pepino. O teor de água de equilíbrio das sementes de pepino diminuiu com o aumento da temperatura em um valor constante de umidade relativa. Os valores de entalpia diferencial, que representam a energia requerida para remover umidade das sementes, variaram de 2923 a 2469 kJ. kg-1. Entropia diferencial e energia livre de Gibbs decresceram com o aumento do teor de água. A teoria da compensação de entalpia-entropia é válida para a sorção de sementes de pepino, em que a sorção de água nas sementes de pepino é controlada pela entalpia.
\end{abstract}

Termos para indexação: teor de água de equilíbrio, entropia, energia livre de gibbs, Cucumis sativus L.

\section{Introduction}

Cucumber (Cucumis sativus L.) is a vegetable of great importance in Brazil due to social and economic value, consumed as salad or canned vegetables. Because of its

${ }^{1}$ Submitted on $05 / 11 / 2015$. Accepted for publication on $07 / 07 / 2015$.

${ }^{2}$ Departamento de Engenharia Agrícola, Universidade Federal de Viçosa, 36570-000 -Viçosa, MG, Brasil.

${ }^{3}$ Faculdade de Guanambi, 46430-000, Guanambi, BA, Brasil. increasing production and aggregated value of cucumber seeds, it is important to study new technologies and problems solution regarding post-harvest procedures.

Among these procedures, drying and storage are widely known and used. In order to accomplish these post-harvest

${ }^{4}$ Instituto Federal do Sudeste de Minas Gerais, 36905-000 - Manhuaçu, MG, Brasil.

${ }^{5}$ Universidade Federal de Mato Grosso - Sinop, MT, Brasil.

*Corresponding author<gabriel.oliveira@ifsudestemg.edu.br> 
operations, knowledge of the relationship between temperature and relative humidity of the air is required. Otherwise, higher probability of insect and microorganisms attack at the seeds is observed, allowing toxin appearance. Thus, physiological quality of the seeds is devalued, hardening or even not feasible its commercialization.

Moisture content of the product, when at equilibrium with the environment, is called equilibrium moisture content or hygroscopic equilibrium. This parameter is useful in order to determine gain or loss of water under certain temperature and relative humidity condition, affecting directly drying and storage processes (Goneli et al., 2013).

Moisture content affects directly vigor and germination of seeds (Moreano et al., 2011), leading to products respiration alterations. Generally, in order to prevent quality loss of seeds during storage, prediction of moisture content due to hygroscopic equilibrium at different environment condition is of great importance. Storage period of seeds multiplies by two for each $1 \%$ reduction in moisture content (when moisture content ranges from $6 \%$ to $20 \%$ wet basis) and for every $5.5{ }^{\circ} \mathrm{C}$ reduction in storage temperature (range from $4.4^{\circ} \mathrm{C}$ to $37.8^{\circ} \mathrm{C}$ ), according to Harrington (1960).

Relationship between equilibrium moisture content and the equilibrium relative humidity of a certain product, at a constant temperature, may be expressed by mathematical equations. These relationships are denominated sorption isotherms or hygroscopic equilibrium curves. There are more than 200 equations in order to represent the hygroscopic equilibrium phenomenon of agricultural products. These models differs from each other due to theoretical or empirical basis and on the amount of parameters involved (Yanniotis and Blahovec, 2009).

Hygroscopic equilibrium curves or sorption isotherms are important in order to define dehydration limits of the product, estimate moisture content alterations under environment conditions and to acquire safe moisture content values. These values are critical in order to prevent unwanted microorganisms activity during storage. In addition, sorption isotherms indicates the required energy in order to dry the product, represented by the isosteric heat of sorption values (Noshad et al., 2012).

Sorption isotherms and isosteric heat of sorption for dried products are essential information to model the different processes from the food industry and for their storage (Gabas et al., 2007). Furthermore, important information in respect to sorption mechanisms and interaction among the products components and moisture can be obtained.

Development of drying equipment, calculations of the energy required to dry products, water properties on food surface and sorption kinetic parameters are some of the items that the thermodynamic properties would be useful information for (Corrêa et al., 2007).

In view of the importance of understanding the hygroscopicity of agricultural products, this work aimed to determine and model the desorption isotherms of cucumber seeds for various temperature and air relative humidity conditions. Also, thermodynamic properties (isosteric heat of desorption, differential entropy, enthalpy-entropy relationship and Gibbs free energy) were obtained.

\section{Material and Methods}

Cucumber seeds with initial moisture content of $38.0 \%$ (w.b.) were used for the desorption process. Cucumber seeds were harvested and retrieved from mature fruits at the Experimental Station from EMGOPA, Anápolis city (Goiás State, Brazil), hybrid "Caipira" type, Anápolis 796. Samples were stored at polypropylene bags of low density, stored in a refrigerator for maintenance and uniformity of moisture content. Previously to analysis, samples were retrieved from the refrigerator and placed on environmental conditions, during two hours, in order to prevent temperature effect. The static method was used in order to obtain hygroscopic equilibrium. Samples were placed inside desiccators containing saturated saline solutions specific for each desired relative humidity, according to Table 1.

Table 1. Relative humidities (decimal) established inside the desiccators for determination of hygroscopic equilibrium of cucumber seeds by means of static method.

\begin{tabular}{lccccc}
\hline \multirow{2}{*}{ Saline solution } & \multicolumn{5}{c}{ Temperature $\left({ }^{\circ} \mathrm{C}\right)$} \\
\cline { 2 - 6 } $\mathrm{LiCl}$ & 0.13 & - & 0.11 & 0.12 & 0.11 \\
$\mathrm{CaCl}$ & 0.40 & 0.35 & - & - & - \\
$\mathrm{Ca}\left(\mathrm{NO}_{3}\right)_{2}$ & 0.59 & 0.55 & - & - & - \\
$\mathrm{NH} \mathrm{Nl}$ & 0.81 & - & - & - & - \\
$\mathrm{NaCl}$ & - & 0.76 & 0.76 & 0.75 & 0.75 \\
$\mathrm{KBr}$ & - & 0.84 & - & - & - \\
$\mathrm{K}_{2} \mathrm{SO}_{4}$ & - & - & - & 0.96 & - \\
$\mathrm{MgCl}_{2}$ & - & - & 0.32 & - & - \\
$\mathrm{KNO}_{2}$ & - & - & 0.47 & - & - \\
$\mathrm{KNO}_{3}$ & 0.96 & 0.93 & 0.91 & - & - \\
$\mathrm{MgCl}_{2} \times \mathrm{H}_{2} \mathrm{O}$ & - & - & - & 0.32 & 0.31 \\
$\mathrm{Na}_{2} \mathrm{Cr}_{2} \mathrm{O}_{7}$ & - & - & - & 0.50 & 0.46 \\
\hline
\end{tabular}

Desiccators containing samples were placed in chambers for temperature control for $(10,20,30,40$ e 50$){ }^{\circ} \mathrm{C}$. Each sample was composed by $100 \mathrm{~g}$ of the product, weighted periodically during the desorption process. Hygroscopic equilibrium was reached when mass variation, between 
three consecutive weightings, was equal or inferior to 0.01 g. Moisture content was determined by applying the oven method at $105 \pm 1{ }^{\circ} \mathrm{C}$ for $24 \mathrm{~h}$, in three repetitions, by means of modified methodology by Brasil (2009).

Experimental data of hygroscopic equilibrium were fitted to five mathematical models (Table 2).

Table 2. Mathematical models used to represent sorption isotherms.

\begin{tabular}{lcc}
\hline \multicolumn{1}{c}{ Model } & Equation & Equation number \\
\hline Modified Oswin (Chen and Morey, 1989) & $M=a+b T /[(1-R H) / R H]^{1 / c}$ & (1) \\
Modified Henderson (Thompson et al., 1968) & $M=\{\ln (1-R H) /[-a \times(T+b)]\}^{1 / c}$ & $(2)$ \\
Modified Halsey (Iglesias and Chirife, 1976) & $M=[\exp (a-b T) /-\ln (R H)]^{1 / c}$ & (3) \\
Copace (Corrêa et al., 1995) & $M=\exp (a-b T+c R H)$ & (4) \\
Chung-Pfost (Pfost et al., 1976) & $M=a-b \ln [-(T+c) \ln (R H)]$ & (5) \\
\hline
\end{tabular}

In which: M - Equilibrium moisture content, \% d.b.; RH - Relative humidity, decimal; $\mathrm{T}$ - Temperature, ${ }^{\circ} \mathrm{C} ; \mathrm{a}, \mathrm{b}, \mathrm{c}$ - Coefficients that depends upon the product.

Differential entropy of desorption $(\Delta S)$, differential enthalpy $(\Delta H)$, Gibbs free energy $(\Delta G)$ and enthalpy-entropy relationship were obtained by means of a known methodology (Corrêa et al., 2012), which an approximate (1- $\alpha) 100 \%$ confidence interval for isokinetic temperature is used. These parameters are expressed respectively by Equations 6 to 10 .

$$
\begin{gathered}
\ln a_{w}= \pm\left(\frac{\Delta H_{s t}}{R T}-\frac{\Delta S}{R}\right) \\
\Delta H=\Delta H_{s t}-\Delta H_{v a p} \\
\Delta G= \pm R T \ln a_{w} \\
T_{B}=\hat{T}_{B} \pm t_{m-2, \alpha / 2} \sqrt{\operatorname{Var}\left(T_{B}\right)} \\
T_{h m}=\frac{n_{t}}{\sum_{i=1}^{n_{t}}\left(\frac{1}{T_{i}}\right)}
\end{gathered}
$$

In which: $\Delta \mathrm{H}=$ isosteric heat of sorption, $\mathrm{kJ}^{\mathrm{kg}} \mathrm{kg}^{-1} ; \Delta \mathrm{H}_{\text {vap }}=$ latent heat of vaporization of pure water, $\mathrm{kJ} \mathrm{kg}^{-1} ; \Delta \mathrm{H}_{\text {st }}=$ net isosteric heat of sorption, $\mathrm{kJ} \mathrm{kg}^{-1} ; \Delta \mathrm{S}=$ differential entropy of sorption, $\mathrm{kJ}$. $\mathrm{kg}^{-1} \mathrm{~K}^{-1}$; and $\Delta \mathrm{G}=$ Gibbs free energy, $\mathrm{kJ} \mathrm{kg}^{-1} \mathrm{~mol}^{-1} ; \mathrm{T}_{\mathrm{B}}=$ isokinetic temperature, $\mathrm{K} ; \mathrm{m}=$ number of data pairs of enthalpy and entropy; $\mathrm{t}=\mathrm{t}$ value at $(\mathrm{m}-2)$ degrees of freedom; $\mathrm{T}_{\mathrm{hm}}=$ harmonic mean temperature, $\mathrm{K}$; and $\mathrm{n}_{\mathrm{t}}=$ number of temperatures utilized.

The experimental data of hygroscopic equilibrium of cucumber seeds were submitted to a regression analysis and an adequate mathematical model was selected to express the relationship between the variables studied. In order to analyze the fitting degree of each model, the magnitudes of the adjusted determination coefficient $\left(\mathrm{R}^{2}\right)$ (explained variance), mean relative error (MRE), the standard deviation of the estimate (SDE), and the analysis of the residual plots generated by the models were used.

The residuals (the difference between the observed values and the estimated values by the models) were plotted through the models as a function of the estimated values. A model was considered to be suitable if the residual values were next to the horizontal line around zero, indicating no tendency in the results. If the residual presented a distribution with tendency, the model is considered inadequate to represent the studied phenomenon. The values of MRE and SDE are calculated as described below:

$M R E=\frac{100}{n} \sum \frac{|Y-\hat{Y}|}{Y} \quad$ (11) $\quad S D E=\sqrt{\frac{\sum(Y-\hat{Y})^{2}}{D F}}$

In which: $\mathrm{MRE}=$ mean relative error, $\% ; \mathrm{SDE}=$ standard deviation of the estimate, $\%$ d.b.; $Y=$ observed value, $\%$ d.b.; $\hat{\mathrm{Y}}=$ estimated value by the model, \% d.b.; $\mathrm{n}=$ number of observed data; and, DF = residue degrees of freedom (number of observed data minus number of model parameters).

\section{Results and Discussion}

Table 3 presents the model parameters fitted to desorption experimental data of cucumber seeds, obtained at different temperature and relative humidity conditions.

At Table 3 it is observed that mathematical models used to describe hygroscopicity presented elevated values of determination coefficient $\left(\mathrm{R}^{2}\right)$, higher than 96\%. However, $\mathrm{R}^{2}$ and the standard deviation of the estimate (SDE) are not sufficient to prove the fitting quality of a model, requiring the analysis of MRE and residual plots. Throughout the results (Table 3), Chung-Pfost and Copace models are not suitable to predict the sorption of cucumber seeds, because they presented values higher than $10 \%$ of MRE, according to Mohapatra and Rao (2005). 
Table 3. Model parameters of hygroscopic equilibrium of cucumber seeds obtained by desorption, with its respective determination coefficients $\left(\mathrm{R}^{2}\right)$, standard deviation of the estimate (SDE), mean relative error (MRE) and residual plots.

\begin{tabular}{|c|c|c|c|c|c|}
\hline Models & Parameters & $\mathrm{R}^{2}$ & SDE & MRE & Residual plot \\
\hline & $a=28.7711$ & & & & \\
\hline \multirow[t]{2}{*}{ Chung-Pfost } & $\mathrm{b}=5.7958$ & 96.91 & 2.1547 & 22.3315 & Biased \\
\hline & $c=22.7606$ & & & & \\
\hline & $\mathrm{a}=0.6683$ & & & & \\
\hline \multirow[t]{3}{*}{ Copace } & $b=0.0096$ & 97.44 & 1.8387 & 17.3195 & Biased \\
\hline & $c=2.9348$ & & & & \\
\hline & $a=4.7758$ & & & & \\
\hline \multirow[t]{3}{*}{ Modified Halsey } & $b=0.0271$ & 97.96 & 1.1791 & 7.3507 & Random \\
\hline & $c=2.1996$ & & & & \\
\hline & $\mathrm{a}=8.2 \times 10^{-4}$ & & & & \\
\hline \multirow[t]{3}{*}{ Modified Henderson } & $\mathrm{b}=50.9792$ & 98.29 & 1.6086 & 6.7204 & Random \\
\hline & $\mathrm{c}=1.2078$ & & & & \\
\hline & $\mathrm{a}=9.9637$ & & & & \\
\hline \multirow[t]{2}{*}{ Modified Oswin } & $b=-0.0849$ & 98.40 & 1.5566 & 9.2449 & Random \\
\hline & $\mathrm{c}=2.5276$ & & & & \\
\hline
\end{tabular}

In order to conclude which model is more suitable, Figure 1 show the residual plots for the remaining models as a function of estimated values of hygroscopic equilibrium of cucumber seeds. Residues were obtained by the difference between experimental and estimated values for each model.

From Figure 1, it is observed that Modified Halsey, Modified Henderson and Modified Oswin presented random residual distribution, indicating an adequate fitting to experimental data. Among these models, Modified Henderson is a traditional model used to represent hygroscopicity. Thus, Modified Henderson model was the one chosen to represent experimental data of desorption process of cucumber seeds at these conditions of temperature and relative humidity. Similar results were reported in previous work, which Modified Henderson model fitted to experimental data of pearl millet grain submitted at the same temperature and relative humidity conditions (Goneli et al., 2010).

Figure 2 reports the behavior of experimental values of equilibrium moisture content of cucumber seeds, obtained by desorption, and its isotherms constructed by means of Modified Henderson model.

It can be noticed an increase of equilibrium moisture content with water activity increment at a constant temperature, fact also reported by other authors (Hessini et al., 2015; Thys et al., 2010). Sigmoid shape type of isotherms is observed at all temperatures studied. This shape is typical for amorphous materials rich in hydrophilic compounds (AlMuhtaseb et al., 2004). This is in agreement with the results obtained for pinhão flour (Cladera-Olivera et al., 2011) and pinhão seeds (Thys et al., 2010).

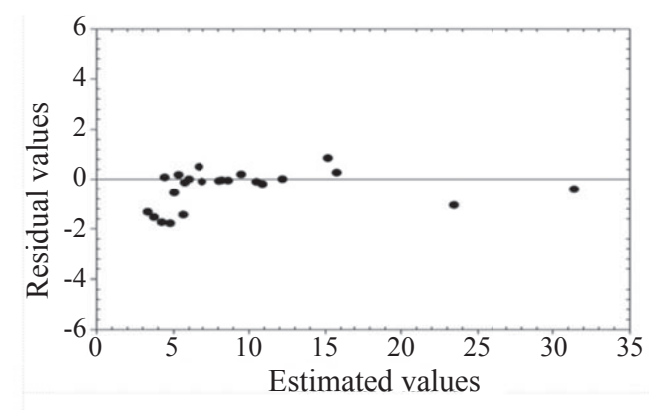

A

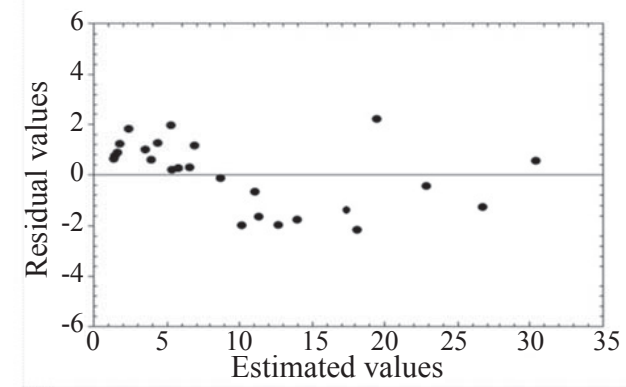

B

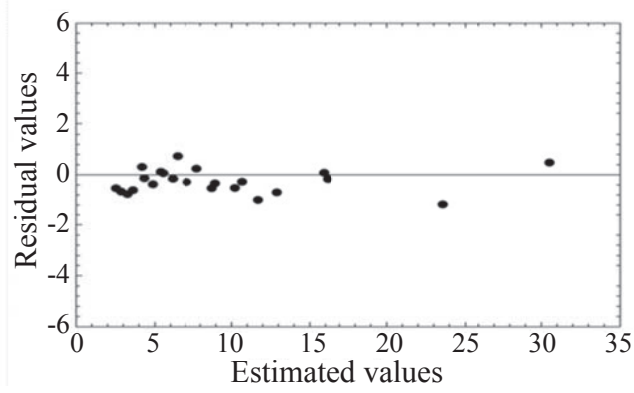

C

Figure 1. Residual plots of mathematical models (A-Modified Halsey, B - Modified Henderson, C - Modified Oswin) for desorption process of cucumber seeds. 


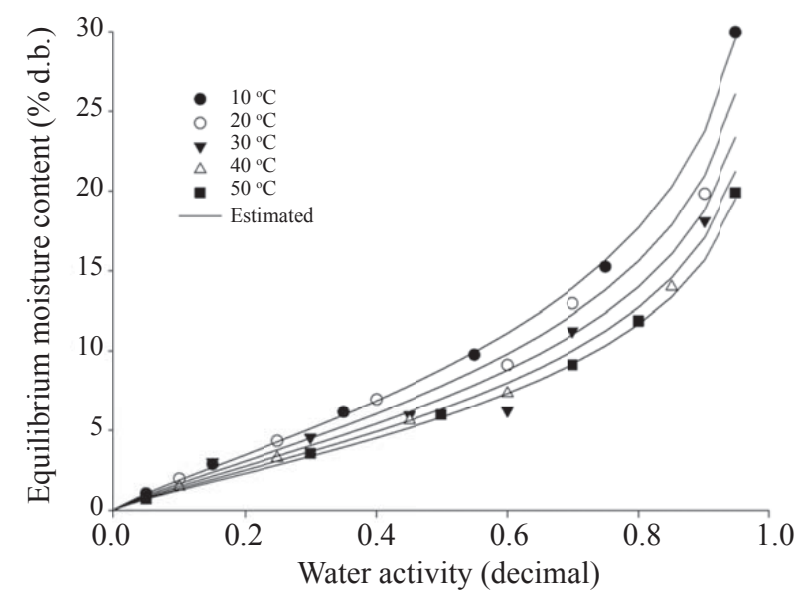

Figure 2. Observed and estimated values by Modified Henderson model of equilibrium moistures content obtained by desorption of cucumber seeds.

This sigmoidal shape can be explained by the amounts of water binding, and can be divided in three regions: below $\mathrm{a}_{\mathrm{w}}$ of $0.3,0.3<\mathrm{a}_{\mathrm{w}}<0.7$ and above 0.7 (Labuza, 1975). In the first region, moisture is due to structural water, which is hydrogen bonded, and monolayer water, which is adsorbed by hydrophilic and polar groups of the grain components (Oliveira et al., 2010). Given that structural water is not available, there is low or no insect propagation and fungi cannot develop (Bewley and Black, 1994). The same authors reported that the fungi development is decreased with equilibrium moisture content values below the upper limit of the multilayer region, which is the second region of the isotherm (in the range $0.3-0.7 \mathrm{a}_{\mathrm{w}}$ ).

The second region is marked by the connection between several layers and the first layer of water by hydrogen bonds, and within this range, respiration rate of seeds increases rapidly, leading to quality loss. In the third region, above an $\mathrm{a}_{\mathrm{w}}$ of 0.7 , water molecules are easily kept within void spaces of the grain due to a capillary region. This makes the grain available to insects and fungi, and deteriorates the product.

Equilibrium moisture content presented decreased values with temperature increase at constant values of RH. This trend is related to the reduced number of available sites at the product in order to occur bonds between water molecules and the products components. This is the result from physical and/ or chemical alterations promoted by the temperature, since it affects the water molecules mobility. At higher temperatures, water molecules are in a higher excitement state, thus increasing the distance and decreasing attractive forces among themselves (Oliveira et al., 2011). This fact leads to a reduction of water sorption degree at a constant $\mathrm{RH}$, with temperature increase.

By means of these isotherms, it is possible to handle cucumber seeds adequately aiming the maintenance of its moisture content at recommended values for a safe storage. Furthermore, sorption isotherms can be employed to define more adequate year time for storage of cucumber seeds at different regions, taking into account the temperature and relative humidity of the local site. The importance of these data is higher in the case of seeds, in which at inadequate storage conditions may lead to germination during storage, which is not desirable.

Figure 3 presents the behavior of differential enthalpy as a function of equilibrium moisture content.

Moisture content reduction leads to an increase of required energy in order to remove moisture from the product (Figure 3), represented by the differential enthalpy values, trend also observed by Moreira et al. (2008). For the moisture content range between 2.0 and $31.0 \%$ (d.b.), the values of this thermodynamic parameter varied between 2923 and $2469 \mathrm{~kJ}^{\mathrm{kg}} \mathrm{kg}^{-1}$.

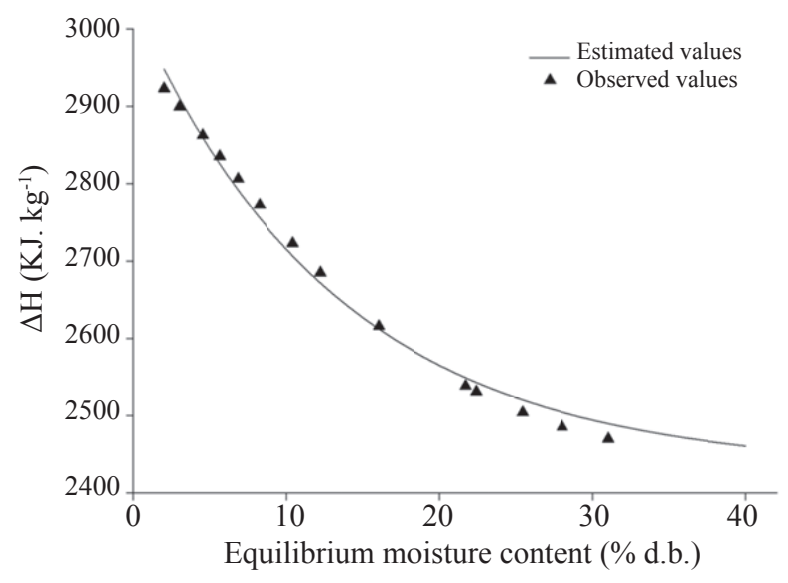

Figure 3. Observed and estimated values of differential enthalpy of desorption as a function of equilibrium moisture content.

It can be also noticed from Figure 3 that values of differential enthalpy of desorption are higher than the latent heat of vaporization of water $\left(2430.50 \mathrm{~kJ}^{\mathrm{kg}} \mathrm{kg}^{-1}\right)$. This trend indicates that bonding energy between water molecules and sorption sites is higher than the bonding energy of water molecules among themselves at the liquid phase (Oliveira et al., 2011). Differences encountered between observed values of differential enthalpy to different products is due to inherent factors of the products and due to possible errors of acquiring the water activity values, since these are retrieved from mathematical models.

Figure 4 demonstrate the differential entropy of desorption values as a function of equilibrium moisture content. According to Figure 4, there is a strong dependence between differential entropy of sorption and moisture content, 
with a similar tendency observed for differential enthalpy. Similar results were observed for starch powder (Al-Muhtaseb et al., 2004) and sesame seeds (Kaya and Kahyaoglu, 2006).

According to the second law of thermodynamics, a process is reversible when the sum of all entropy changes at all subsystems of a process is constant. By means of Figure 4 , it is noticed that with moisture content increment there is a reduction of differential entropy, with the tendency to reach constant value at higher moisture content values. This trend indicates that at a certain point of moisture content, sorption process is reversible (Madamba et al., 1996). The minimum integral entropy can be interpreted as the water activity at which the product has the best stability of a food product (Domínguez et al., 2007).

Table 4 reports the mathematical model fitted to the observed values of differential enthalpy and differential entropy of desorption as a function of equilibrium moisture content. It is observed that equations are suitable to predict the phenomenon, presenting significant regression parameters and elevated values of determination coefficient.

Values of differential enthalpy as a function of differential entropy values of desorption are presented at Figure 5. It was considered that to a certain value of moisture content, differential enthalpy and differential entropy are invariant with temperature.

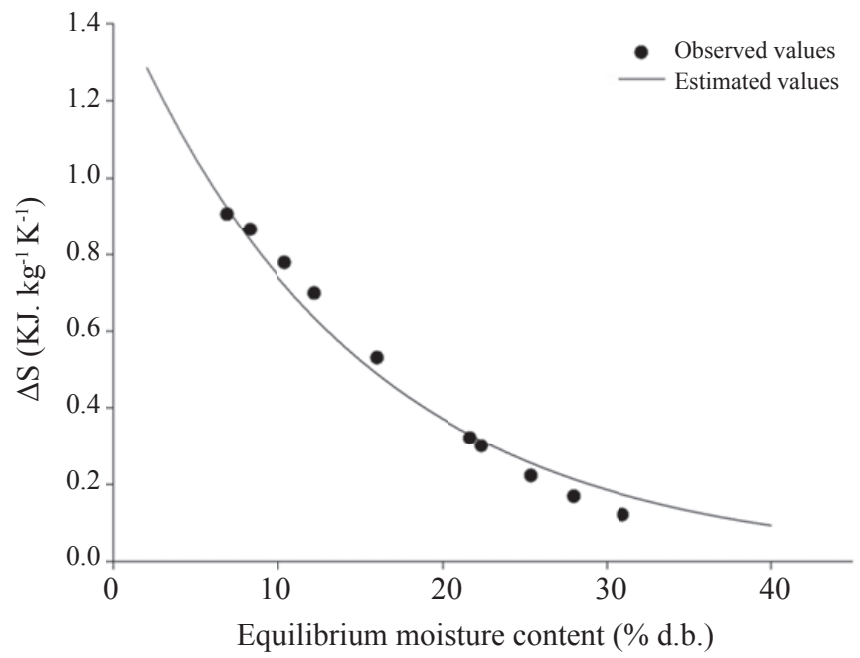

Figure 4. Observed and estimated values of differential entropy of desorption $(\Delta S)$ of cucumber seeds as a function of equilibrium moisture content.

Table 4. Mathematical model fitted to the observed values of differential enthalpy of desorption $\left(\Delta \mathrm{H}, \mathrm{kJ} \mathrm{kg}^{-1}\right)$ and differential entropy of desorption $\left(\Delta \mathrm{S}, \mathrm{kJ} \mathrm{kg}^{-1} \mathrm{~K}^{-1}\right)$, as a function of equilibrium moisture content (\% d.b.) with their respective determination coefficient $\left(\mathrm{R}^{2}\right)$.

\begin{tabular}{ccc}
\hline Thermodynamic property & Regression equation & $\mathrm{R}^{2}(\%)$ \\
\hline Differential enthalpy & $\Delta \mathrm{H}=601.5359 \times \exp \left(-0.0750 \times M_{e}\right)+2430.50$ & 99.12 \\
Differential entropy & $\Delta \mathrm{S}=1.4767 \times \exp \left(-0.0691 \times M_{e}\right)$ & 97.72 \\
\hline
\end{tabular}

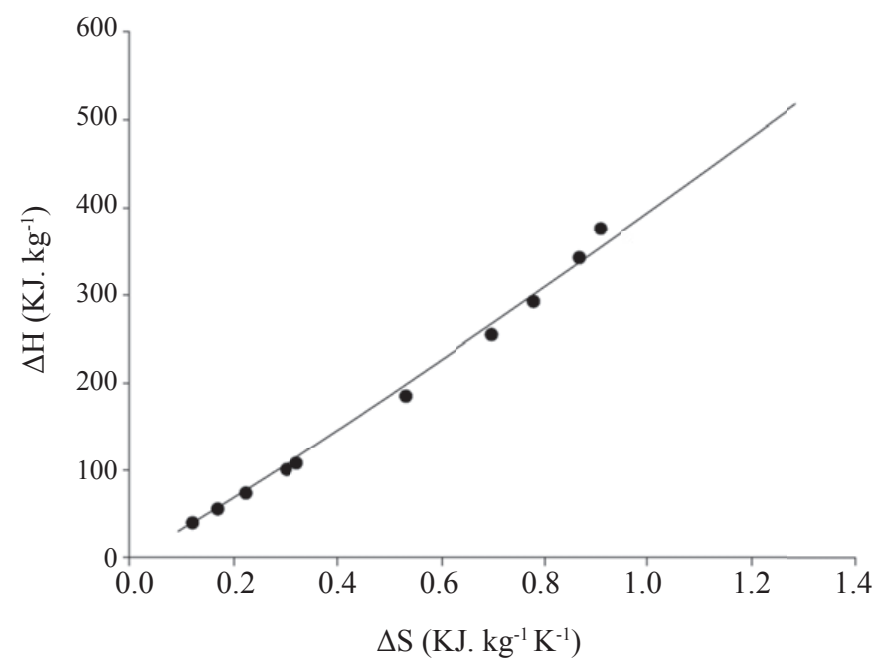

Figure 5. Enthalpy - entropy relationship for desorption process of cucumber seeds.
It can be observed that there is a linear relationship between these two thermodynamic properties, with determination coefficient higher than $99 \%$. Isokinetic temperature $\left(\mathrm{T}_{\mathrm{B}}\right)$ and Gibbs free energy $\left(\Delta G_{B}\right)$ at $T_{B}$ were determined by means of linear regression and its results are demonstrated at Table 5.

In order to validate the theory of enthalpy-entropy compensation, isokinetic temperature was compared to the mean harmonic temperature $\left(\mathrm{T}_{\mathrm{hm}}\right)$ obtained from the temperature range used to acquire the sorption isotherms. Linear chemical compensation only exists if $T_{B}$ is different from $\mathrm{T}_{\mathrm{hm}}$ (Corrêa et al., 2012).

Harmonic temperature calculated was $302.33 \mathrm{~K}$, value significantly different from isokinetic temperature (Table 5), confirming that the enthalpy-entropy compensation theory is valid for the sorption of cucumber seeds.

Isokinetic temperature is the one at which all reactions in sequence must occur at the same time; in other words, when the product is in equilibrium (Liu and Guo, 2001). If $\mathrm{T}_{\mathrm{B}}>\mathrm{T}_{\mathrm{hm}}$, 
the process is enthalpy controlled; when $T_{B}<T_{h m}$, the process is controlled by entropy (Leffler, 1955). Since the $T_{B}$ values of the present work led to the former condition, the water sorption mechanism in cucumber seeds can be considered to be enthalpy controlled. These results are in agreement with several studies that have successfully applied the isokinetic theory to the sorption of different products, concluding that the sorption phenomenon is enthalpy controlled (Goneli et al., 2013; Goneli et al., 2010; Oliveira et al., 2010; Madamba et al., 1996).

Table 5. Characteristically parameters obtained for the enthalpy-entropy relationship of desorption process of cucumber seeds.

\begin{tabular}{ccc}
\hline $\mathrm{T}_{\mathrm{B}}(\mathrm{K})$ & $\Delta \mathrm{G}_{\mathrm{B}}\left(\mathrm{kj} \cdot \mathrm{kg}^{-1}\right)$ & $\mathrm{R}^{2}(\%)$ \\
\hline $406.0978 \pm 0.002$ & -13.1511 & 99.94 \\
\hline
\end{tabular}

Figure 6 demonstrates the Gibbs free energy behavior at the five different temperatures used. It can be noticed that there is a decrease of $\Delta \mathrm{G}$ with an increment of equilibrium moisture content. This trend can be correlated to the vibration of water molecules within the product, where at high temperatures this vibration (movement) is higher; this leads to lower work required to the product layers to become available to sorption. At high levels of equilibrium moisture content, temperature influence becomes negligible due to the sorption sites are already available (Goneli et al., 2013). Positive values of $\Delta \mathrm{G}$ are also expected, as it characterizes endothermic reaction, or else, reactions that require energy from the environment to occur.

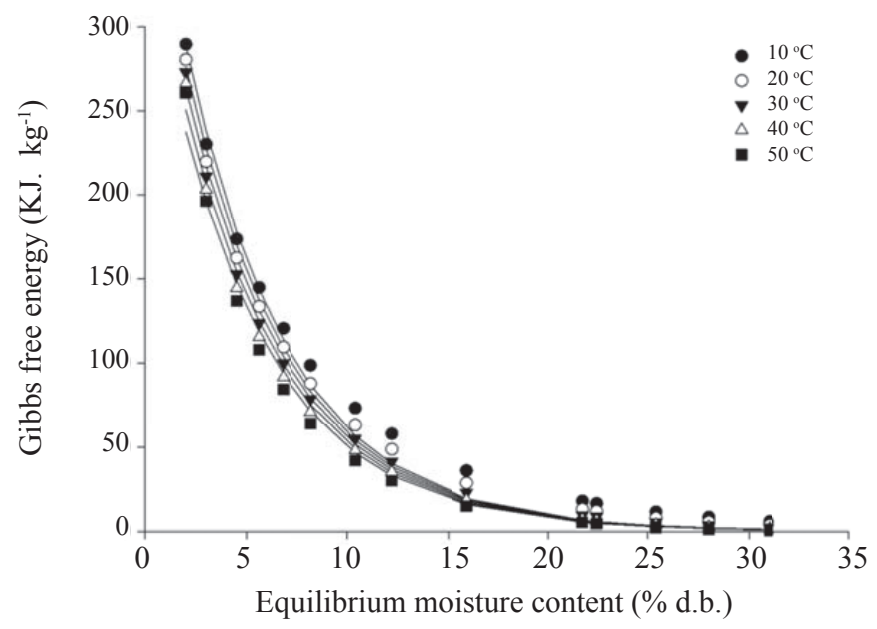

Figure 6. Observed and estimated values of Gibbs free energy from desorption of cucumber seeds as a function of equilibrium moisture content.

\section{Conclusions}

According to the results, it can be concluded that desorption process was well represented by the Modified Halsey, Modified Oswin and Modified Henderson model. Hygroscopic equilibrium of cucumber seeds is directly proportional to water activity and decreases with temperature increment at a constant value of relative humidity.

Differential enthalpy, differential entropy and Gibbs free energy presented high correlation with the equilibrium moisture content of cucumber seeds, and the enthalpyentropy compensation theory exists, being desorption process of cucumber seeds enthalpy controlled.

\section{References}

AL-MUHTASEB, A.H.; MCMINN, W.A.M.; MAGEE, T.R.A. Water sorption isotherms of starch powders. Part 2: Thermodynamic characteristics. Journal of Food Engineering, v.62, n.2, p.135-142, 2004. http://www. sciencedirect.com/science/article/pii/S0260877403002024

BEWLEY, J.D.; BLACK, M. Seeds: physiology of development and germination, 2ed. Plenum Press, New York, 1994. 445p.

BRASIL. Ministério da Agricultura, Pecuária e Abastecimento. Regras para análise de sementes. Ministério da Agricultura, Pecuária e Abastecimento. Secretaria de Defesa Agropecuária. Brasília: MAPA/ACS, 2009. 395p. http:// www.agricultura.gov.br/arq_editor/file/2946_regras_analise_sementes.pdf

CHEN, C.; MOREY, R.V. Comparison of four EMC/ERH equations. Transactions of the ASAE, v.32, n.3, p.983-990, 1989.

CLADERA-OLIVERA, F.; MARCZAK, L.D.F.; NOREÑA, C.P.Z.; PETTERMANN, A.C. Modeling water adsorption isotherms of pinhão (Araucaria angustifolia seeds) flour and thermodynamic analysis of the adsorption process. Journal of Food Process Engineering, v.34, n.3, p.826-843, 2011. http://onlinelibrary.wiley.com/doi/10.1111/j.1745-4530.2009.00437.x/pdf

CORRÊA, P.C.; OLIVEIRA, G.H.H.; SANTOS, E.S. Thermodynamic properties of agricultural products processes. In: ARANA, I. (Ed.). Physical properties of foods: Novel measurement techniques and applications, 1ed. Boca Raton: CRC Press, 2012. p131-141.

CORRÊA, P.C.; GONELI, A.L.D.; JAREN, C.; RIBEIRO, D.M.; RESENDE, O. Sorption isotherms and isosteric heat of peanut pods, kernels and hulls. Food Science and Technology International, v.13, n.3, p.231-238, 2007. http://fst. sagepub.com/content/13/3/231.full.pdf + html

CORRÊA, P.C.; MARTINS, D.S.R.; MELO, E.C. Umigrãos: Programa para o cálculo do teor de umidade de equilíbrio para os principais produtos agrícolas; UFV: Viçosa, 1995. 10p.

DOMÍNGUEZ, I. L.; AZUARA, E.; VERNON-CARTER, E. J. ; BERISTAIN, C. I. Thermodynamic analysis of the effect of water activity on the stability of macadamia nut. Journal of Food Engineering, v.81, p.566-571, 2007. http:// www.sciencedirect.com/science/article/pii/S0260877407000039

GABAS, A.L.; TELIS, V.R.N.; SOBRAL, P.J.A. ; TELIS-ROMERO, J. Effect of maltodextrin and Arabic gum in water vapor sorption thermodynamic properties of vacuum dried pineapple pulp powder. Journal of Food Engineering, v.82, p.246252, 2007. http://www.sciencedirect.com/science/article/pii/S0260877407001197 
GONELI, A.L.D.; CORRÊA, P.C.; OLIVEIRA, G.H.H. ; AFONSO JÚNIOR, P.C. Water sorption properties of coffee fruits, pulped and green coffee. LWT - Food Science and Technology, v.50, n.2, p.386-391, 2013. http://www.sciencedirect.com/science/article/pii/S0023643812003866

GONELI, A.L.D.; CORRÊA, P.C.; OLIVEIRA, G.H.H.; BOTELHO, F.M. Water sorption isotherms and thermodynamic properties of pearl millet grain. International Journal of Food Science and Technology, v.45, n.4, p.828-838, 2010. http://onlinelibrary.wiley.com/doi/10.1111/j.1365-2621.2010.02208.x/abstract

HARRINGTON, J.F. Thumb rules of drying seeds. Crops \& Soils, v.13, n1, p.16-17, 1960 .

HESSINI, L.; BETTAIEB, E.; DESMORIEUX, H.; TORRES, S. S. ; TOUIL, A. Desorption isotherms and thermodynamic properties of prickly pear seeds. Industrial Crops and Products, v.67, p.457-465, 2015. http://www. sciencedirect.com/science/article/pii/S0926669015000801

IGLESIAS, H.; CHIRIFE, J. Prediction of the effect of temperature on water sorption isotherms of food material. Journal of Food Technology, v.11, n.2, p.109-116, 1976.

KAYA, S.; KAHYAOGLU, T. Influence of dehulling and roasting process on the thermodynamics of moisture adsorption in sesame seed. Journal of Food Engineering, v.76, n.2, p.139-147, 2006. http://www.sciencedirect. com/science/article/pii/S0260877405003092

LABUZA, T.P. Interpretation of sorption data in relation to the state of constituent water. In: DUCKWORTH, R.B. (Ed.). Water Relations of Foods. London: Academic Press, 1975. p.155-172.

LEFFLER, J.E. The enthalpy-entropy relationship and its implications for organic chemistry. The Journal of Organic Chemistry, v.20, n.9, p.12021231, 1955.

LIU, L.; GUO, Q.X. Isokinetic relationship, isoequilibrium relationship, and enthalpy-entropy compensation. Chemical Reviews, v.101, p.673-695, 2001. http://pubs.acs.org/doi/pdf/10.1021/cr990416z

MADAMBA, P.S.; DRISCOLL, R.H.; BUCKLE, K.A. Enthalpy-entropy compensation models for sorption and browning of garlic. Journal of Food Engineering, v.28, n.2, p.109-119, 1996. http://www.sciencedirect.com/ science/article/pii/0260877494000727

MOHAPATRA, D.; RAO, P.S. A thin layer drying model of parboiled wheat. Journal of Food Engineering, v.66, p.513-18, 2005. http://www.sciencedirect. com/science/article/pii/S0260877404001888
MOREANO, T.B.; BRACCINI, A.L.; SCAPIM, C.A.; KRZYZANOWSKI, F.C.; FRANÇA-NETO, J.B.; MARQUES, O.J. Changes in the effects of weathering and mechanical damage on soybean seed during storage. Seed Science and Technology, v.39, p.604-611, 2011. http://www.ingentaconnect. com/content/ista/sst/2011/00000039/00000003/art00007

MOREIRA, R.; CHENlO, F.; TORRES, M. D.; VALLEJO, N Thermodynamic analysis of experimental sorption isotherms of loquat and quince fruits. Journal of Food Engineering, v.88, p.514-521, 2008. http:// www.sciencedirect.com/science/article/pii/S0260877408001398

NOSHAD, M.; SHAHIDI, F.; MOHEBBI, M.; MORTAZAVI, S. Desorption isotherms and thermodynamic properties of fresh and osmotic-ultrasonic dehydrated quince. Journal of Food Processing Preservation, v.37, p.1-12, 2012. http://onlinelibrary.wiley.com/doi/10.1111/j.1745-4549.2011.00671.x/abstract

OLIVEIRA, G.H.H.; CORRÊA, P.C.; ARAÚJO, E.F.; VALENTE, D.S.M.; BOTELHO, F.M. Desorption isotherms and thermodynamic properties of sweet corn cultivars (Zea mays L.). International Journal of Food Science and Technology, v.45, n.3, p.546-554, 2010. http://onlinelibrary.wiley.com/ doi/10.1111/j.1365-2621.2009.02163.x/abstract

OLIVEIRA, G. H. H.; CORRÊA, P. C.; SANTOS, E. S.; TRETO, P. C. ; DINIZ, M. D. M. S. Evaluation of thermodynamic properties using GAB model to describe the desorption process of cocoa beans. International Journal of Food Science and Technology, v.46, p.2077-2084, 2011. http:// onlinelibrary.wiley.com/doi/10.1111/j.1365-2621.2011.02719.x/abstract

PFOST, H.B.; MOURER, S.G.; CHUNG, D.S.; MILLIKEN, G.A. Summarizing and reporting equilibrium moisture data for grains. Technical Report, 76-3520. American Society of Agricultural Engineers, St Joseph, 1976.

THOMPSON, T.L.; PEART, R.M.; FOSTER, G.H. Mathematical simulation of corn drying: A new model. Transactions of the ASAE, v.11, n.4, p.582-586, 1968.

THYS, R. C. S.; NOREÑA, C. P. Z.; MARCZAK, L. D. F.; AIRES, A. G.; CLADERA-OLIVERA, F. Adsorption isotherms of pinhão (Araucaria angustifolia seeds) starch and thermodynamic analysis. Journal of Food Engineering, v.100, p.468-473, 2010. http://www.sciencedirect.com/science/ article/pii/S0260877410002293

YANNIOTIS, S.; BLAHOVEC, J. Model analysis of sorption isotherms LWT - Food Science and Technology, v.42, p.1688-1695, 2009. http://www. sciencedirect.com/science/article/pii/S0023643809001467 